\title{
Physico-Chemical Characterization and Stability Study in Acidic and Basic Solution of Ceramic Filters from Mouka's Clay (Cameroon)
}

\author{
Ngiongboung Nguiamba*, Placide Désirée Belibi Belibi, Joseph Marie Sieliechi, \\ Martin Benoît Ngassoum \\ Department of Applied Chemistry, University of Ngaoundéré, Ngaoundéré, Cameroon \\ Email:^ronnynguiamba@gmail.com,mr.belibibelibi@yahoo.fr, jsieliechi@yahoo.fr,ngassoum@yahoo.fr
}

How to cite this paper: Nguiamba, N., Belibi, P.D.B., Sieliechi, J.M. and Ngassoum, M.B. (2019) Physico-Chemical Characterization and Stability Study in Acidic and Basic Solution of Ceramic Filters from Mouka's Clay (Cameroon). Journal of Materials Science and Chemical Engineering, 7, 42-53.

https://doi.org/10.4236/msce.2019.711005

Received: April 1, 2019

Accepted: November 25, 2019

Published: November 28, 2019

Copyright $\odot 2019$ by author(s) and Scientific Research Publishing Inc. This work is licensed under the Creative Commons Attribution International License (CC BY 4.0).

http://creativecommons.org/licenses/by/4.0/

\section{(c) (7) Open Access}

\begin{abstract}
This paper deals with the characterisation and study of physico-chemical stability of ceramic filters from clays and rice husk obtained from the far north region of Cameroon (Logone Valley) and their application in potable water treatment. Clays from Mouka were characterized by FTIR analysis. The results showed that the filter formulated with a mixture containing $80 \%$ clay and $20 \%$ rice husk of $100 \mu \mathrm{m}$ in size each gave the lowest filter shrinkage rate; these formulated filters were chosen for the remaining work. Leaching tests showed that with filters at a sintering temperature of $830^{\circ} \mathrm{C}$ the leaching was not observed under neutral ( $\mathrm{pH} 6.8)$ and acidic ( $\mathrm{pH}$ 5) conditions as compared to $950^{\circ} \mathrm{C}$ and $1000^{\circ} \mathrm{C}$ where the leaching was observed. In basic (pH 9) condition, all the filters obtained released ions. Leaching tests revealed that the conductivity of the leachate for the filters sintered at $830^{\circ} \mathrm{C}$ was lower than those sintered at $950^{\circ} \mathrm{C}$ and $1000^{\circ} \mathrm{C}$. Meanwhile, conductivity decreases with increasing sintering temperature (temperature up to $830^{\circ} \mathrm{C}$ ) due to the fact that ceramization starts as from $850^{\circ} \mathrm{C}$ that leads to an amorphous state that favours chemical stability, the leaching ions were $\mathrm{Fe}^{2+}, \mathrm{Ca}^{2+}, \mathrm{Mg}^{2+}$ and $\mathrm{Al}^{3+}$. The ceramic filters sintered at $950^{\circ} \mathrm{C}$ were applied to the filtration of water and the performance in terms of turbidity reduction was $95 \%$ and the flow rate after 50 minutes was $100 \times 10^{-3} \mathrm{~L} / \mathrm{h}$.
\end{abstract}

\section{Keywords}

Ceramic Filter, Chemical Stability, Clay, Filtration, Lixiviation Test

\section{Introduction}

According to World Health Organization, over one billion people do not have 
access to safe drinking water. In Cameroon, disparities between urban and rural areas are evident. In fact, $48 \%$ and $5 \%$ of rural and urban inhabitants use surface water or other unimproved water sources. Previous monitoring programs executed in the Logone Valley in the Far North region of Cameroon reported high turbidity in water resources. Turbidity is a typical problem of surface water and shallow open wells, as observed in the studies carried out in Cameroon.

Ceramic membranes for water filtration are one of the alternative techniques for treatment of drinking water [1]. Ceramic water filtration is the process of passing water through a porous ceramic material. It is a promising way to reduce the burden of water-borne diseases; it is affordable in terms of cost and made from local resources [2]. It has been shown that ceramic filters can reduce turbidity [3] and microorganism [2]. Meanwhile, physico-chemical properties of ceramic filters such as porosity and chemical stability are important to evaluate the filter efficiency. These properties are linked to the amount of porogen and sintering temperature. Previous works in the field have shown that porosity of ceramic filters decreases with increase in firing temperature for the same composition of clay and porogen fired at different temperatures [4] and that the physico-chemical stability increases with increase in firing temperature due to the formation of more crystalline phase such as mullite [5]. But no matter the crystalline phase present in the material it's stability can be influenced by the physico-chemical properties of the feed water such as $\mathrm{pH}$. Recent monitoring programs executed in the Logone Valley in the Far North region of Cameroon reported that $\mathrm{pH}$ of surface water could be either acidic and basic with maximum values of 5 and 9 respectively. If ceramic filters based on Mouka clay have been already investigated on treating drinking water [3] there is no information about their behavior under acidic and basic conditions. The new challenge is therefore to state if under specific feed water condition ceramic filters will or not be able to leach metal pollutant in treated water. Nowadays, ceramic membranes can be obtained with high separation coefficient, but at the same time, this fact supposes low permeate fluxes. For each application, it is necessary to look for the adequate combination between selectivity and permeation. The choice of these parameters depends on the type of clay used, the type of porogen, and the ratio between clay and porogen. In this research, ceramic filters based on materials from the Logone Valley (clay and rice husk) were formulated. Study of the effect of fabrication method on parameters such as retention of suspended mater and chemical stability of the ceramic membranes was investigated.

\section{Main Body}

\subsection{Sampling and Characterization of Raw Materials}

Clay material was collected at a mining site located at Mouka (Far North region of Cameroon) altitude $323 \mathrm{~m}$, latitude $10.34716^{\circ} \mathrm{N}$ and longitude $15.25248^{\circ} \mathrm{E}$. Rice husks were collected at Yagoua (Far North region of Cameroon) market. After collection, the clay and rice husks were stored and dried at room tempera- 
ture in the laboratory. The clay was ground using an artisanal (made of wood) mortar while the rice husk was ground using a grinding mill (farmer mill used to grind corn). The clay and rice husk were sieved to obtain two different diameters $(-50 \mu \mathrm{m}$ and $-100 \mu \mathrm{m})$ of powder. The clay was subjected to mineralogical analysis by FTIR. Chemical compositions of both clay and rice husks powders were analysed using a wavelength dispersive X-Ray fluorescence (Shimadzu XRF-1800).

\subsection{Preparation and Characterization of Ceramic Membranes}

The preparation of the porous support was achieved by mixing clay and rice husk powders with water, to produce a homogenous paste. The homogenous paste contained different clay: rice husk weight ratio of 0.6:0.4; 0.7:0.3 and 0.8:0.2. For each ratio, the mixture of clay: rice husk powders consist of sizes of $-100:-100 \mu \mathrm{m},-100:-50 \mu \mathrm{m}$ and $-50:-50 \mu \mathrm{m}$ respectively. The volume of water necessary to get a moldable paste varied depending on the mixture. The paste was then moulded in an annular cylindrical (stainless steel) of $36 \mathrm{~mm}$ internal diameter, $59 \mathrm{~mm}$ height and a thickness of $5 \mathrm{~mm}$. The obtained material was then dried first at room temperature for 24 hours, then at $50^{\circ} \mathrm{C}$ for 6 hours and $100^{\circ} \mathrm{C}$ for 42 hours in a drying oven (Crouzet, France) for complete removal of moisture. Afterwards the membranes were sintered in a muffle furnace (Nabertherm, Germany) at various temperatures $\left(830^{\circ} \mathrm{C}, 950^{\circ} \mathrm{C}\right.$ and $\left.1000^{\circ} \mathrm{C}\right)$ for 8 hours with 2 heating rates; the first one was $5^{\circ} \mathrm{C} / \mathrm{min}$ until $500^{\circ} \mathrm{C}$ and then $10^{\circ} \mathrm{C} /$ min until one of the 3-desired final sintering temperatures was reached. The final temperature was kept for 2 hours then the muffle furnace was cooled gradually to room temperature. Before and after sintering, the membrane dimensions were measured to evaluate the shrinkage (diameter, height). The open porosity was determined by the Archimedes method (using water as immersion fluid) [6].

The dissolution study of the ceramic membranes was performed by two experiments: study of the conductivity of water as a function of time under fixed $\mathrm{pH}$ and the lixiviation test.

In the first experiment, solutions were prepared at $\mathrm{pH} 5$ and 9 (using hydrochloric acid and sodium hydroxide in distilled water). Distilled water was used in the case of $\mathrm{pH}$ 7. For each test, water was introduced into the filter and maintained constant by continuous addition. The conductivity of the filtrate was measured by sampling $20 \mathrm{ml}$ of filtrate.

In the lixiviation test, the ceramic membrane was immersed in distilled water in a container at the ratio Liquid/Solid $(\mathrm{L} / \mathrm{S})=10$ [7] the container was then put in a shaker for 24 hours at $30 \mathrm{rpm}$. After this time the $\mathrm{pH}$ and conductivity of the water were measured using a multiparameter $\mathrm{pH}$-conductivity instrument (Hach, HQ40d). The determination of Iron and Aluminium released in solution was done using a colorimetric method (Molecular absorption spectrometer) with a UV-Visible spectrophotometer (spectroquant Pharo $100 \mathrm{M}$ ). The determination of Calcium and Magnesium was done by titration with Ethylene Diamine Tetra Acetic Acid (EDTA). 


\subsection{Microfiltration Studies}

\subsubsection{Preparation of Kaolinite Suspension}

Approximately $1.500 \mathrm{~g}$ of kaolinite sample was soaked in $3 \mathrm{~L}$ of distilled water for 24 hours. And let to rest for 8 hours to settle larger particles before decanting the liquid. The particle size distribution in the decanted suspension was obtained by mastersizer (Malvern hydro 2000SM). The analysis showed that $6.66 \%$ of the particles had sizes $\leq 0.93 \mu \mathrm{m} ; 33.33 \%$ of the particles had sizes $\leq 1.088 \mu \mathrm{m}$ and $60 \%$ of particles had sizes $\leq 1.16 \mu \mathrm{m}$.

\subsubsection{Filtration Test}

Turbidity of 100 Nephelometric Turbidity Unit (NTU) was obtained by simple dilution of the later suspension with distilled water. The turbidity was determined by using a nephelometric turbidimeter (HACH RATIO 2100A). The filter was placed on a funnel on top of a collecting beaker and then filled with the suspension and maintained constantly full by continuously adding on. Filtration was carried out at atmospheric pressure. The filtrate was recovered as a function of time, turbidity and conductivity measurements were also performed. Blank tests were carried out with distilled water before using the membranes.

\section{Results and Discussion}

\subsection{Characterization of Raw Materials}

\subsubsection{Chemical Characterization}

Chemical properties using XRF were assessed. As shown in Table 1, the major chemical component of Mouka clay is $\mathrm{SiO}_{2}$, with $47.47 \mathrm{wt} \%$ for particles of average size $<100 \mu \mathrm{m}$. The percentage of $\mathrm{Al}_{2} \mathrm{O}_{3}$ corresponds to non-refractory clay since it does not exceed $45 \%$ [3]. There is also a small quantity of alkali with values between $0.22 \%$ and $0.76 \%$ as $\mathrm{Na}_{2} \mathrm{O}$ and $0.99 \mathrm{wt} \%$ and $3.1 \mathrm{wt} \%$ as $\mathrm{K}_{2} \mathrm{O}$ showing that this clay sample matures at relatively high temperatures [8]. Table 1 also shows that the percentage of $\mathrm{CaO}$ is $7.51 \mathrm{wt} \%$ which is higher than $6 \mathrm{wt} \%$, characteristic of calcareous clay [9]. The percentage of iron is $6.9 \mathrm{wt} \%$ which is under the limit allowable values (8wt\%) for using in the ceramic industry [10]. The percentage of other components is lower than $1 \%$. The Loss of ignition (Loi) of clay is in the range of $8 \%-18 \%$ allowable for ceramics [11]. For rice husk, the high percentage of Loi showed that this can create pores.

\subsubsection{Phase Identification}

The FTIR spectrum (Figure 1) showed absorption bands at $3693.67 \mathrm{~cm}^{-1}$, $3620.63 \mathrm{~cm}^{-1}, 910.03 \mathrm{~cm}^{-1}, 791.82 \mathrm{~cm}^{-1}$ and $524.21 \mathrm{~cm}^{-1}$ indicating the presence of kaolinite [12]. The presence of illite is confirmed by absorption bands at

Table 1. Chemical composition (wt\%) of the Mouka clay and rice husk.

\begin{tabular}{ccccccccccccc}
\hline & $\mathrm{S}_{\mathrm{i}} \mathrm{O}_{2}$ & $\mathrm{Al}_{2} \mathrm{O}_{3}$ & $\mathrm{Fe}_{2} \mathrm{O}_{3}$ & $\mathrm{CaO}$ & $\mathrm{MgO}$ & $\mathrm{Na}_{2} \mathrm{O}$ & $\mathrm{K}_{2} \mathrm{O}$ & $\mathrm{SO}_{3}$ & $\mathrm{TiO}_{2}$ & $\mathrm{Mn}_{2} \mathrm{O}_{3}$ & $\mathrm{P}_{2} \mathrm{O}_{5}$ & $\mathrm{Loi}^{1}$ \\
\hline Mouka & 47.47 & 15.60 & 6.95 & 7.51 & 0.66 & 0.67 & 2.43 & 0.11 & 1.31 & 0.04 & 0.08 & 16.22 \\
Rice husk & 17.35 & 0.67 & 0.48 & 5.62 & 0.15 & 0.03 & 0.51 & 0.02 & 0.07 & 0.03 & 0.23 & 69.47 \\
\hline
\end{tabular}




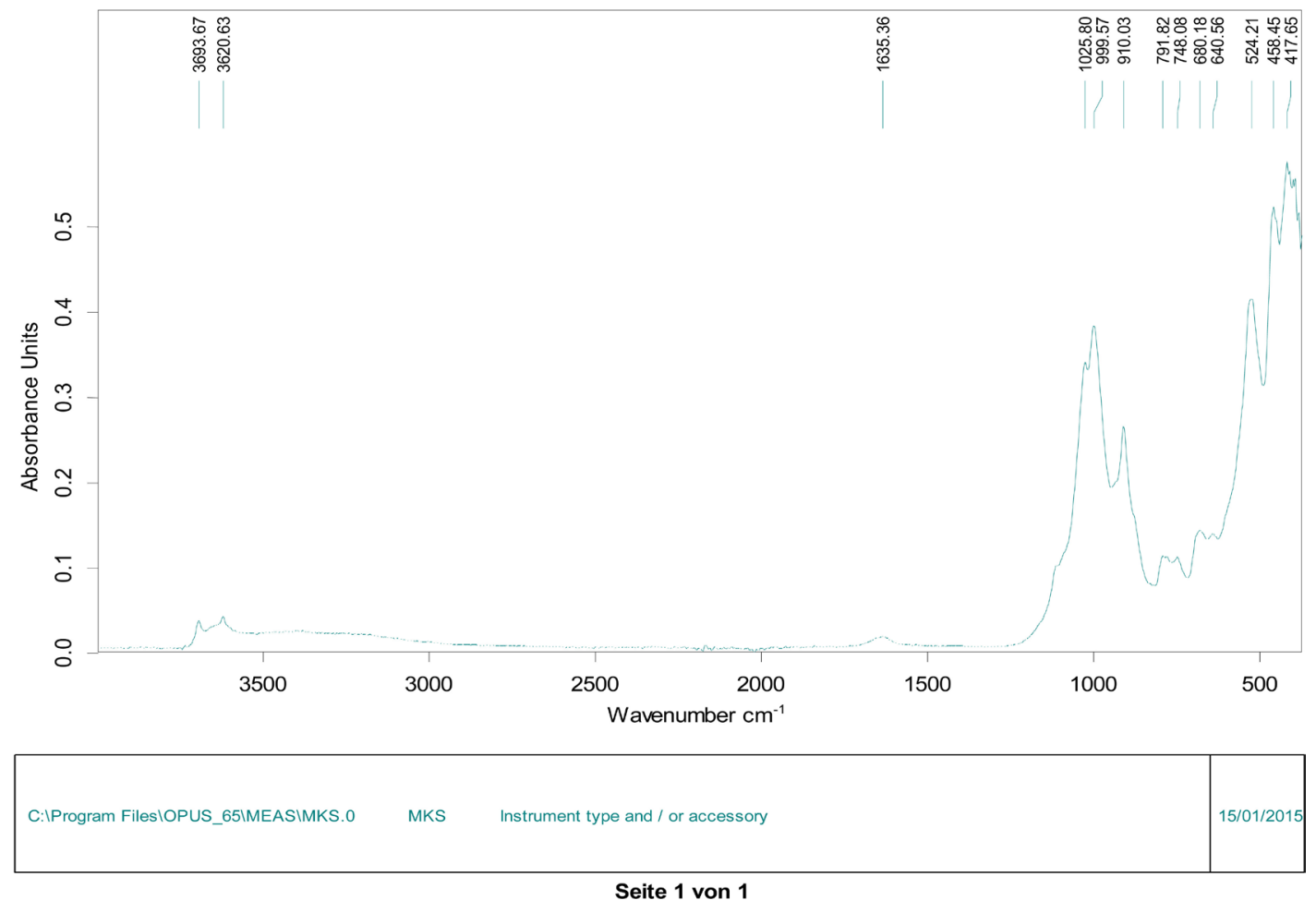

Figure 1. FTIR spectrum of Mouka clay.

$1635.36 \mathrm{~cm}^{-1}, 1025.80 \mathrm{~cm}^{-1}, 910.03 \mathrm{~cm}^{-1}$ and $791.82 \mathrm{~cm}^{-1}$. Also, hematite is present due to the absorption bands at $24.21 \mathrm{~cm}^{-1}$ and $458.45 \mathrm{~cm}^{-1}$ [13].

\subsection{Structural Characterization of Sintered Membranes}

The produced membranes were characterized using XRD and the results are shown in Figure 2; the major crystalline phases identified were mullite $\left(2 \mathrm{Al}_{2} \mathrm{O}_{3} \mathrm{SiO}_{2}\right)$, anorthite $\left(\mathrm{CaAl}_{2} \mathrm{Si}_{2} \mathrm{O}_{8}\right)$ and quartz $\left(\mathrm{SiO}_{2}\right)$. The presence of mullite is due to the presence of illite in the clay [5]. The presence of anorthite just confirms that the clay is a calcareous one (transformation of illite to anorthite instead of spinel) [14]. The high intensities of the quartz peaks are related to the degree of crystallinity of these ceramics when compared to the clay minerals [15]. The Archimedes principle method showed that the porosity was about $30 \%$, which is a value high enough to get efficient membranes for filtration. This porosity was created by incorporating the rice husk material in the clay before heat treatment [2] [16].

\subsection{Influence of Mixture Proportions and Size of Clay and Rice Husk on Withdrawal Thickness}

Table 2 shows the influence of mixture proportions and size of clay and rice husk on shrinkage (percentage of thickness diminution after firing), we observed that when the clay granulometry is $\leq 50 \mu \mathrm{m}$ and rice husk granulometry is $\leq 50$ $\mu \mathrm{m}$, the shrinkage was $46 \%$. In addition, when the clay granulometry is $\leq 100 \mu \mathrm{m}$ and rice husk granulometry is $\leq 50 \mu \mathrm{m}$, the shrinkage was $29 \%$.

When we used the mixture proportion of $70 \%$ of clay $(\varnothing \leq 50 \mu \mathrm{m})$ and $30 \%$ of 
rice husk of $(\varnothing \leq 50 \mu \mathrm{m})$, the shrinkage was $46 \%$. When the proportion of the mixture is $80 \%$ clay $(\varnothing \leq 50 \mu \mathrm{m})$ and $20 \%$ of rice husk $(\varnothing \leq 50 \mu \mathrm{m})$, the shrinkage was $21 \%$. The sharp contraction observed after sintering is due to the phenomenon of expansion and densification taking place during sintering. It appears that less shrinkage occurred when the clay proportion is higher as compared to that of rice husk. The mixture containing $80 \%$ of clay $(\varnothing \leq 100 \mu \mathrm{m})$ and $20 \%$ rice husk permitted the researcher to obtain the lowest shrinkage.

\subsection{Influence of Sintering Temperature on Water of Absorption Capacity of Ceramic Membrane}

The water absorption capacity in a material can be related to its porosity. The porosity is obtained based on the Archimedes method whereby the difference between the mass of the filter before and after immersion in water expressed in percentage gives the porosity. Moreover, the amount of water absorption increases with the amount of porogen added [17]. Hence, pore volume and pore structure are significant parameters that influence the leaching behavior of materials. Table 3 shows the influence of sintering temperature on water absorption

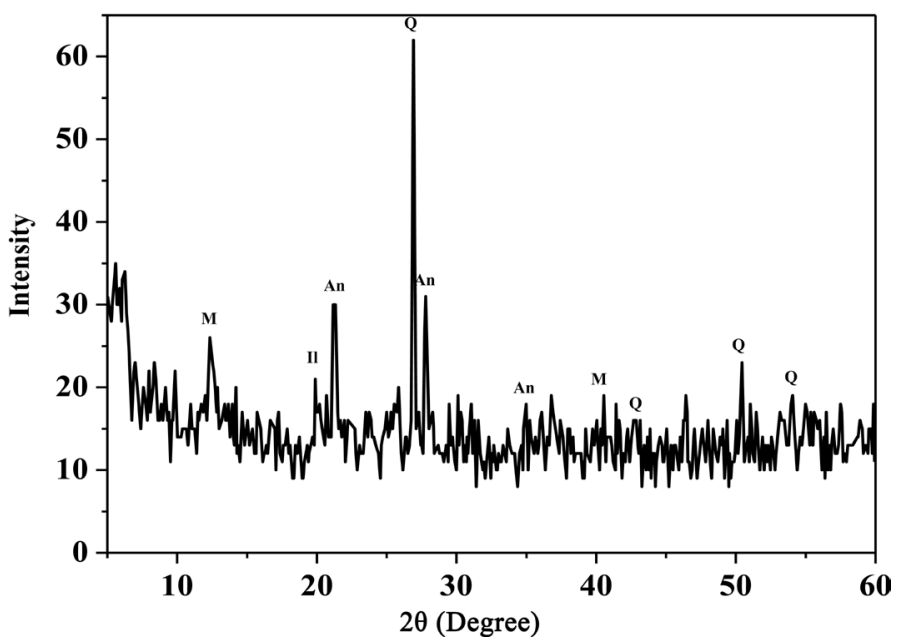

Figure 2. XRD pattern of sintered filters $\left(950^{\circ} \mathrm{C}\right)(\mathrm{Q}=$ quartz, $\mathrm{M}=$ mullite, $\mathrm{An}=$ anhortite, $\mathrm{Il}=$ Illite).

Table 2. Influence of mixture proportions and size of clay and rice husk on shrinkage.

\begin{tabular}{ccccc}
\hline & \multicolumn{2}{c}{$\begin{array}{c}\text { Granulometry of clay and rice husk } \\
\text { Clay:rice husk }\end{array}$} & \multicolumn{2}{c}{$\begin{array}{c}\text { Proportion of clay and rice husk } \\
\text { Clay:rice husk }\end{array}$} \\
\cline { 2 - 5 } & $50: 50 \mu \mathrm{m}$ & $100: 50 \mu \mathrm{m}$ & $70 \%: 30 \%$ & $80 \%: 20 \%$ \\
\hline Shrinkage & $46.00 \%$ & $29.00 \%$ & $46.00 \%$ & $21.00 \%$ \\
\hline
\end{tabular}

Table 3. Influence of sintering temperature on total porosity and pore volume of filters.

\begin{tabular}{cccc}
\hline Temperature & $830^{\circ} \mathrm{C}$ & $950^{\circ} \mathrm{C}$ & $1000^{\circ} \mathrm{C}$ \\
\hline Percentage of void & $30 \%$ & $22 \%$ & $21 \%$ \\
Pore volume & $(17.99 \pm 0.44) \mathrm{cm}^{3}$ & $(11.30 \pm 0.50) \mathrm{cm}^{3}$ & $(8.97 \pm 0.50) \mathrm{cm}^{3}$ \\
\hline
\end{tabular}


and pore volume. It appeared that the water absorption decreased when sintering temperature increased. The porosity decreased from $30 \%$ to $21 \%$ when the sintering temperature increased from $830^{\circ} \mathrm{C}$ to $1000^{\circ} \mathrm{C}$. Also, it can be observed that the porosity decreases sharply from $830^{\circ} \mathrm{C}$ to $950^{\circ} \mathrm{C}$ but slightly from $950^{\circ} \mathrm{C}$ to $1000^{\circ} \mathrm{C}$. The reduction of water absorption capacity is due to the densification of the membrane. In fact, the particles tend to agglomerate with each other with increasing temperature leading to a more consolidated ceramic body. These results are similar to those of [4].

\subsection{Filtration Tests}

The experimental results obtained from the filtration of water with initial turbidity of 100 NTU under a fixed temperature and pressure are presented in Figure 3. The variation of the flow rate as a function of time is presented in Figure $3(a)$. We noted that time has a significant effect on filtration rate. Flow rate dropped sharply to $100 \times 10^{-3} \mathrm{~L} / \mathrm{h}$ during the first $50 \mathrm{~min}$ of filtration. The flow rate reduced more slowly between $50 \mathrm{~min}$ and $150 \mathrm{~min}$ and more slowly again beyond this time. The drop of the flow rate value, observed after $150 \mathrm{~min}$, can be attributed to clogging by suspended particles in the feed water having approximately the same size as the mean pore diameter [18]. The reducing rate corresponds with the observed formation of a coating layer on the surface of the filter. The deposited layer which increased with time reduced the filtration rate. This behavior corresponds to the classical dependence of flux with the time of microfiltration. The decreased permeate flux with the time is due to the formation of a particulate cake [3].

The change of turbidity as a function of the final filtration time is presented in Figure 3(b). Turbidity is the cloudiness or haziness of a fluid caused by individual particles (suspended solids) which are generally invisible to the naked eye. The measurement of turbidity is a key test of water quality. It was observed that the turbidity of water dropped sharply four times less than 25 mins and stabilized
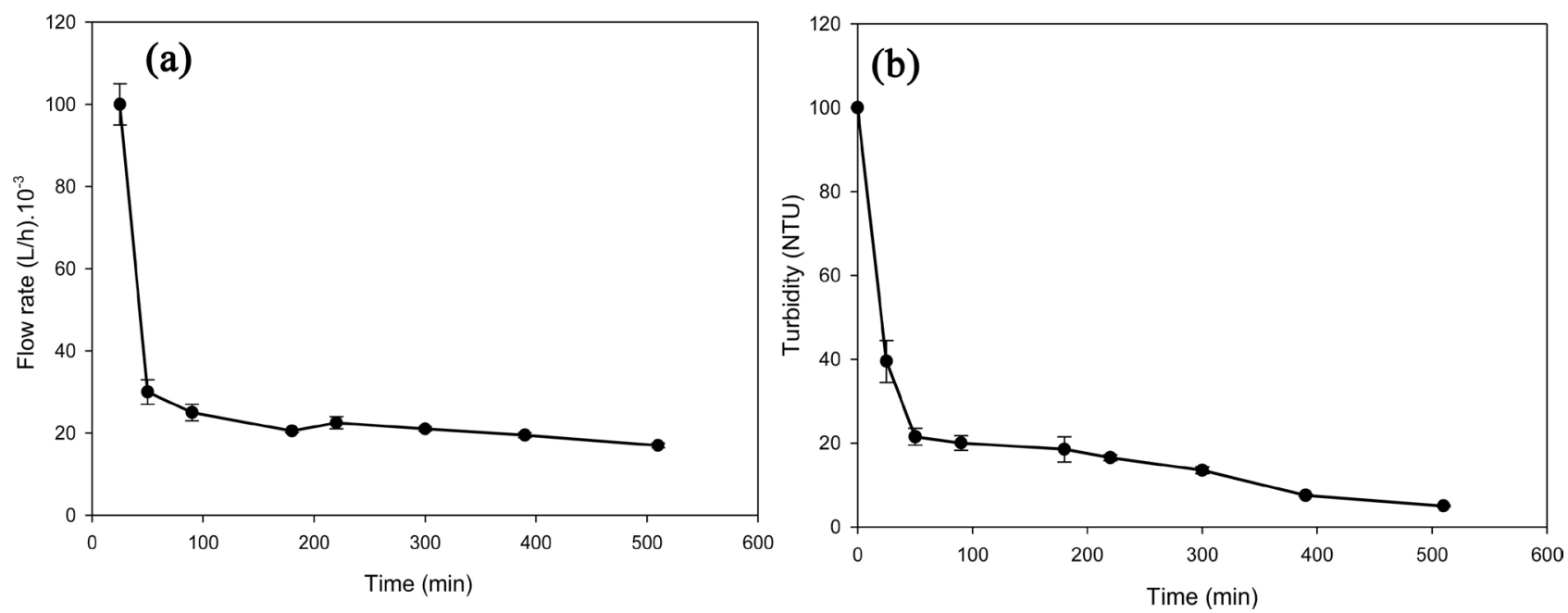

Figure 3. Reduction of flow rate (a) and residual turbidity (b) as a function of time during filtration. 
beyond. The final reduction of turbidity was $95 \%$. The decrease of turbidity during the time of filtration is due to the retention of particle in water. This retention increases with the formation of cake.

\subsection{Physical Characterization: Chemical Stability}

Chemical stability analysis of ceramic filters was done either in acidic, neutral (distilled water) or basic media and the results are shown in Figure 4. In the acidic medium, temperature of sintering and time had a great influence on the final meso-structure of the ceramic filter. The change in conductivity values over time was observed in a solution of $\mathrm{pH}$ 5. For a sintering temperature of $830^{\circ} \mathrm{C}$, the conductivity remained constant with time. On the contrary, sintering temperatures of $950^{\circ} \mathrm{C}$ and $1000^{\circ} \mathrm{C}$, showed an increase in conductivity values, which reached a maximum after $100 \mathrm{mins}(213 \mu \mathrm{S} / \mathrm{cm})$ and $300 \mathrm{~min} .(216.1$ $\mu \mathrm{S} / \mathrm{cm}$ ) respectively. The conductivity then decreased to the initial conductivity. The increase in conductivity is due to an attack of the material in acidic media. In fact, closed pores are opened which therefore release ions into the solution due to the presence of $\mathrm{OH}$ groups. The decrease in conductivity observed after 300 mins is explained by $\mathrm{OH}$ groups in the ceramic forming hydrated components with $\mathrm{H}^{+}$of the acid. This renders some components of material matrix unstable in acidic media. These results show that chemical stability is higher for filters sintered at $830^{\circ} \mathrm{C}$ but the one for $950^{\circ} \mathrm{C}$ was lower than $1000^{\circ} \mathrm{C}$. This is because ceramization starts from $850^{\circ} \mathrm{C}$, which leads to an amorphous state that favors chemical stability.

In distilled water ( $\mathrm{pH}$ 6.8) conductivity also remained constant with time of filtration for a sintering temperature of $830^{\circ} \mathrm{C}$. For a sintering temperature of $950^{\circ} \mathrm{C}$, the conductivity increased to a maximum of $76 \mu \mathrm{S} / \mathrm{cm}$ (after $90 \mathrm{mins}$ ) whereas for a sintering temperature of $1000^{\circ} \mathrm{C}$ the maximum conductivity is 30 $\mu \mathrm{S} / \mathrm{cm}$ (after $180 \mathrm{mins}$ ). After those values, the conductivity slightly decreased with time. This is related to the end of the salting process due to the presence of non-crystalized elements in the structure of the ceramic material. These results can be explained by the fact that when the sintering temperature is increased the porosity decreases, and the material has fewer $\mathrm{OH}$ groups on the surface thus exhibiting higher resistance to degradation in water [19]. In fact, these results show that for a sintering temperature of $830^{\circ} \mathrm{C}$ there are low amount of $\mathrm{OH}$ groups, whereas a sintering temperature of $950^{\circ} \mathrm{C}$ produces more $\mathrm{OH}$ groups than a $1000^{\circ} \mathrm{C}$ sintering temperature.

In basic media ( $\mathrm{pH}$ 9) the initial conductivity dropped at the beginning of filtration whatever the temperature. This decrease is because $\mathrm{OH}^{-}$, ions responsible for the basicity, are absorbed in the structure of the ceramic filter at the beginning of filtration and remain constant over time. It also appeared that the conductivity reduced until after 60 mins when using a filter with sintering temperature of $830^{\circ} \mathrm{C}$. Above this time, the conductivity did not change with an increase of the filtration time. The drop-in conductivity is due to the adsorption of $\mathrm{OH}^{-}$ ions at the surface of the material. 

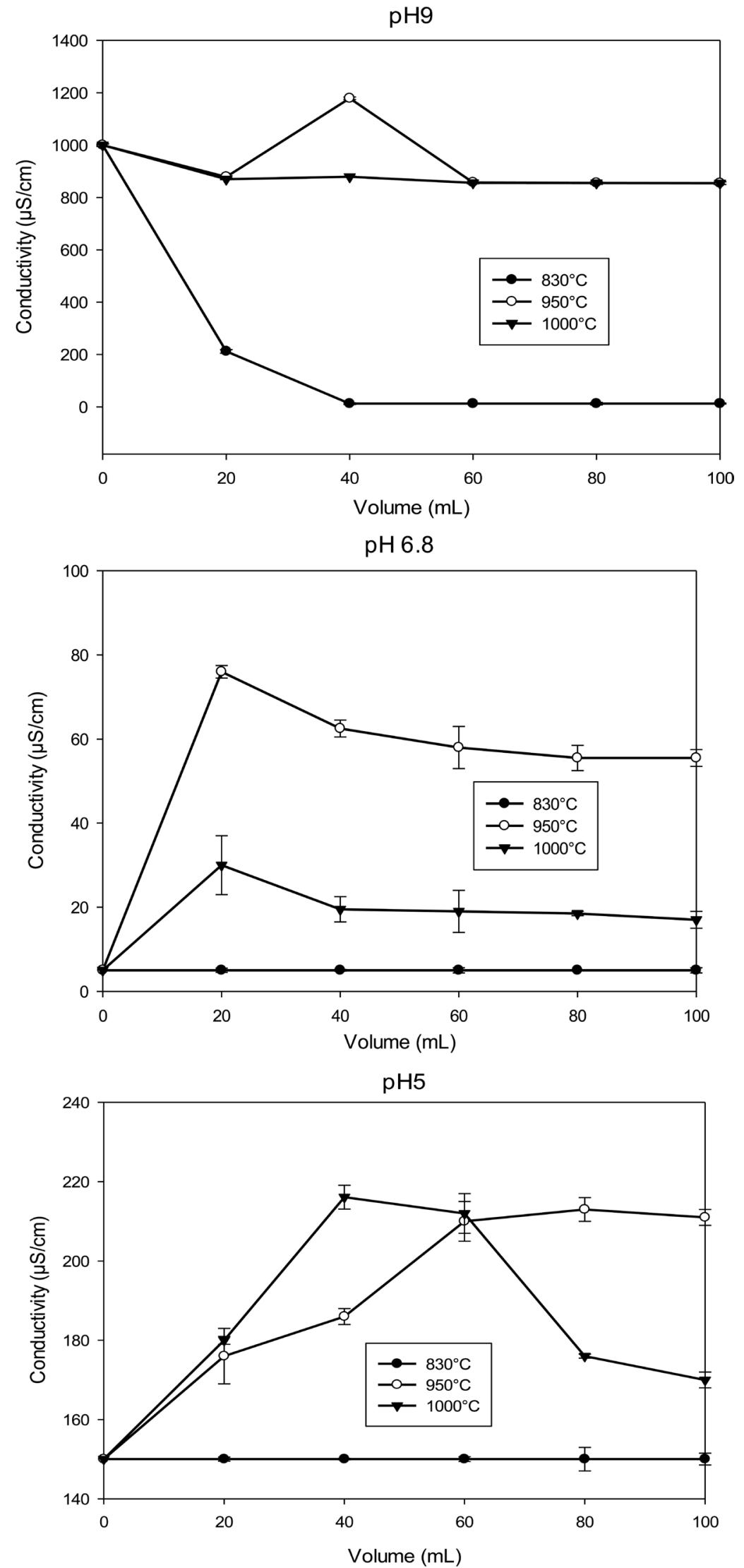

Figure 4. Filtrate's conductivity with $\mathrm{pH}$. 


\subsection{Lixiviation Test}

Figure 5 shows the $\mathrm{pH}$ value (Figure 5(a)) and the metals released (Figure $5(\mathrm{~b}))$ in the lixiviate as a function of the sintering temperature $830^{\circ} \mathrm{C}, 950^{\circ} \mathrm{C}$ and $1000^{\circ} \mathrm{C}$. With initial $\mathrm{pH} 6.8$ (distilled water), we observed an increase in $\mathrm{pH}$ with increasing sintering temperature; $\mathrm{pH}$ increases from 6.4 (a sharp drop as compared to the initial) at $830^{\circ} \mathrm{C}$ to 7.18 at $1000^{\circ} \mathrm{C}$. This observation is due to the higher metal concentration in the solution, the higher $\mathrm{H}^{+}$ions concentration that results from the hydrolysis of metal cations in the water, which triggers a reduction of $\mathrm{pH}$ equilibrium. Therefore, the sintering process reduces the leaching of the metals due to the reactions produced during sintering.

Figure 5(b) shows the metal dissolution as a function of sintering temperature. Iron, Calcium and Aluminium are the major metals released in solution. The amount of Calcium decreased when temperature increased; this is because up to $850^{\circ} \mathrm{C}$ the crystallized phase of Calcium (Calcite) appeared, so the amount of Calcium in the lixiviate is less. The higher amount of Iron and Aluminium released was observed at $950^{\circ} \mathrm{C}$. This is because around $950^{\circ} \mathrm{C} \mathrm{FeO}$ is transformed into $\mathrm{Fe}_{2} \mathrm{O}_{3}$ (Hematite). At temperatures higher than $950^{\circ} \mathrm{C}$, the amount of Iron reduced gradually and for Aluminium, the formation of silicon-spinel appeared. The latter is more crystallized so the leaching behavior is reduced. In fact, as the sintering temperature increased, the material became more crystalline and therefore less subject to degradation in water. High conductivity values obtained in the case where the sintering temperature was $830^{\circ} \mathrm{C}$ shows the high instability of various oxides in the material such as lime $(\mathrm{CaO})$, monocalcium silicate $\left.(\mathrm{CaOSiO})_{2}\right)$, iron oxide $\left(\mathrm{Fe}_{2} \mathrm{O}_{3}\right)$ metakaolin $\left(2 \mathrm{SiO}_{2}, \mathrm{Al}_{2} \mathrm{O}_{3}\right)$ and mullite $\left(2 \mathrm{SiO}_{2}\right.$, $3 \mathrm{Al}_{2} \mathrm{O}_{3}$ ) that were released in solution meaning that at this sintering temperature crystallization phase is limited [20].
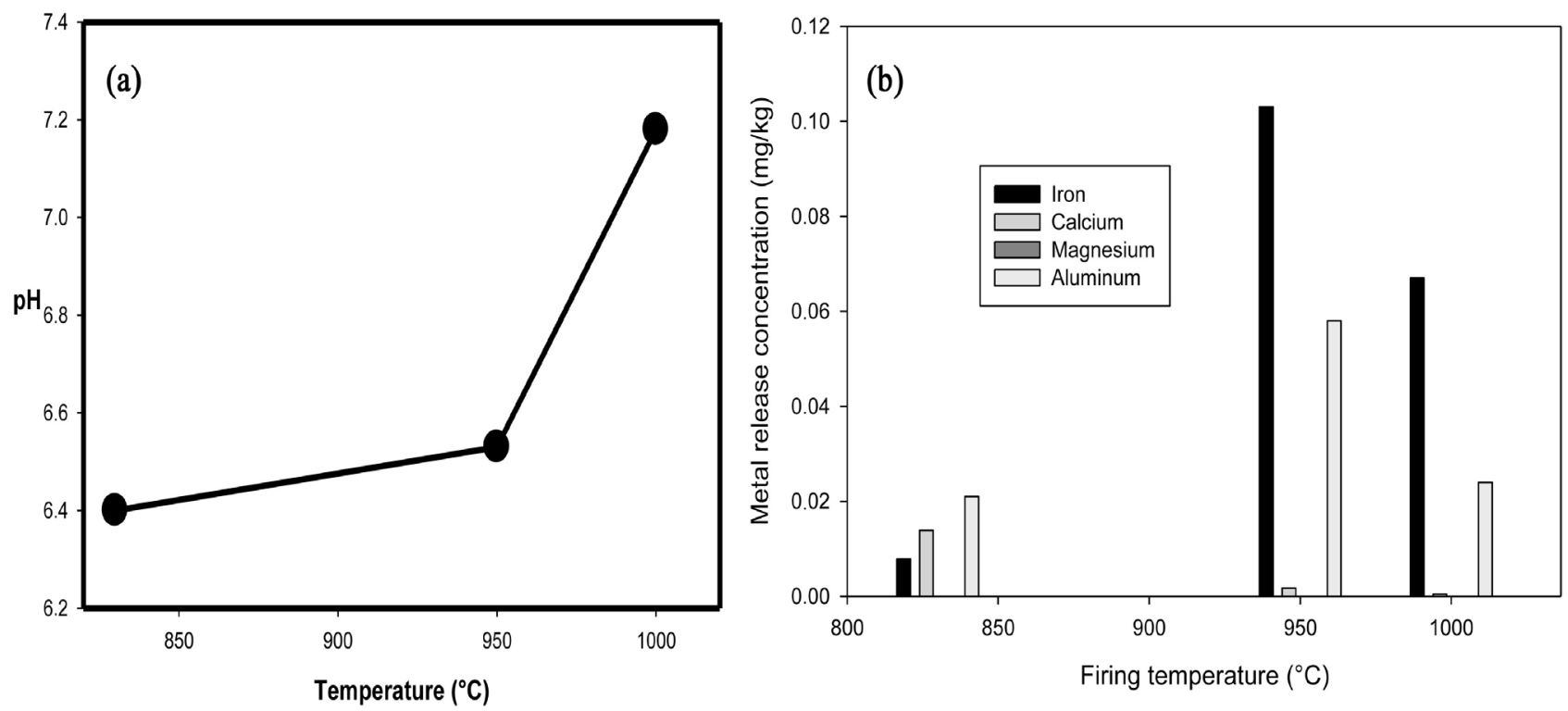

Figure 5. Evolution of $\mathrm{pH}$ (a) and metal release in solution (b) of filtrate as a function of firing temperature $\left(830^{\circ} \mathrm{C}, 950^{\circ} \mathrm{C}\right.$ and $\left.1000^{\circ} \mathrm{C}\right)$. 


\section{Conclusion}

This work shows the application of ceramic membrane filters obtained with local raw materials from the Logone Valley in water treatment. The produced materials can improve the quality of water in terms of turbidity. The proportion of $80 \%$ of clay (milled at diameter $<100 \mu \mathrm{m}$ ) and $20 \%$ of rice husk (milled at diameter $<50 \mu \mathrm{m}$ ) reduced filter shrinkage after sintering. Different measures of conductivity and $\mathrm{pH}$ of the water and leachate showed that the conductivity of the leachate decreases when the sintering temperature increases reflecting an increase in crystallinity of the material when sintering temperature increased. The filtration tests of turbid water exhibited a reduction of turbidity of $95 \%$. These experimental results show that ceramic filter made with Mouka clay and rice husk is an appropriate material for the development of microfiltration membranes which could be applied to drinking water treatment.

\section{Acknowledgements}

The authors thank the Association for Rural Cooperation in Africa and Latin America (ACRA) for financial support.

\section{Conflicts of Interest}

The authors declare no conflicts of interest regarding the publication of this paper.

\section{References}

[1] Van Halem, D., Van Der Laan, H., Soppe, A.I.A. and Heijman, S.G.J. (2017) High Flow Ceramic Pot Filters. Water Research, 124, 398-406. https://doi.org/10.1016/j.watres.2017.07.045

[2] Zereffa, E.A. and Bekalo, T.B. (2017) Clay Ceramic Filter for Water Treatment. Materials Science and Applied Chemistry, 34, 69-74. https://doi.org/10.1515/msac-2017-0011

[3] Belibi Belibi, P.D. (2017) Mise Au Point D’une Membrane Céramique De Microfiltration a Base De Materiau Argileux Du Cameroun: Application a L'élimination De La Kaolinite Des Eaux De Consommation. Ph.D. Dissertation, ENSAI, University of Ngaoundere, Cameroon.

[4] Bulta, A.L. and Micheal, G.A.W. (2019) Evaluation of the Efficiency of Ceramic Filters for Water Treatment in Kambata Tabaro Zone, Southern Ethiopia. Environmental Systems Research, 8, 1. https://doi.org/10.1186/s40068-018-0129-6

[5] Souza, A.E., Teixeira, S.R., Santos, G.T.A. and Longo, E. (2013) Addition of Sedimentary Rock to Kaolinitic Clays: Influence on Sintering Process. Cerâmica, 59, 145-157. https://doi.org/10.1590/S0366-69132013000100017

[6] Khandan, A., Karamian, E., Mehdikhani-Nahrkhalaji, M., Mirmohammadi, H., Farzadi, A., Ozada, N., Heidarshenas, B. and Zamani, K. (2015) Influence of Spark Plasma Sintering and Baghdadite Powder on Mechanical Properties of Hydroxyapatite. Procedia Materials Science, 11, 183-189. https://doi.org/10.1016/j.mspro.2015.11.087

[7] Bassolé, M.R. (2016) Pertinence Des Essais En Batch Dans La Prédiction Du comportement Hydrogéochimique Des Rejets Miniers. Master Dissertation, University 
of Montreal, Quebec.

[8] Jordan, M.M., Pardo, F. and Sanfeliu, T. (2014) Ceramic Behaviour of Some Raw Materials from Ecuador. International Ceramic Review, 63, 36-38.

https://doi.org/10.1007/BF03401033

[9] Javanshah, Z. (2018) Chemical and Mineralogical Analysis for Provenancing of the Bronze Age Pottery From Shahr-I-Sokhta, South Eastern Iran. Scientific Culture, 4, 83-92.

[10] Dondi, M., Raimondo, M. and Zanelli, C. (2014) Clays and Bodies for Ceramic Tiles: Reappraisal and Technological Classification. Applied Clay Sciences, 96, 91-109. https://doi.org/10.1016/j.clay.2014.01.013

[11] Abubakar, I., Birmin Yauri, U.A., Faruq, U.Z., Noma, S.S. and Sharif, N. (2014) Characterization of Dabagi Clay Deposit for Its Ceramics Potential. Academics Journals, 8, 455-459. https://doi.org/10.5897/AJEST2014.1741

[12] Monsif, M., Rossignol, S., Allali, F., Zerouale, A., Idrissi Kandri, N., Joussein, E., Tamburini, S. and Bertani, R. (2016) The Implementation of Geopolymers Materials From Moroccan Clay, within the Framework of the Valorization of the Local Natural Resources. Journal of Materials and Environmental Sciences, 8, 2704-2721.

[13] Salama, W., El Aref, M. and Gaupp, R. (2015) Spectroscopic Characterization of Iron Ores Formed in Different Geological Environment Using FITR, XPS, Mössbauer Spectroscopy and Thermoanalyses. Spectrochimica Acta Part A: Molecular and Biomolecular Spectroscopy, 136, 1816-1826. https://doi.org/10.1016/j.saa.2014.10.090

[14] Dabare, L. and Svinka, R. (2014) Characterization of Porous Ceramic Pellets from Latvian Clays. Chemija 25, 82-88.

[15] Dutra, L.F., Freitas, M.E., Grillet, A.-C., Mendes, N. and Woloszyn, M. (2019) Microstructural Characterization of Porous Clay-Based Ceramic Composites. Materials, 12, 946. https://doi.org/10.3390/ma12060946

[16] Ayala-Landeros, J.G., Saucedo-Rivalcoba, V., Bribiesca-Vasquez, S., Castaño, V.M., Martínez-Hernández, A.L. and Velasco-Santos, C. (2016) Influence of Corn Flour as Pore Forming Agent on Porous Ceramic Material Based Mullite: Morphology and Mechanical Properties. Science of Sintering, 48, 29-39.

https://doi.org/10.2298/SOS1601029A

[17] Agbo, S.C., Ekpunobi, E.U., Onu, C.C. and Akpomie, K.G. (2015) Development of Ceramic Filter Candle From Nsu (Kaolinite Clay) for Household Water Treatment. International Journal of Multidisciplinary Science and Engineering, 6, 18-23.

[18] Soppe, A.I.A., Heijman, S.G.J., Gensburger, I., Shantz, A., Van Halem, D., Kroesbergen, J., Wubbels, G.H. and Smeets, P.W.M.H. (2015) Critical Parameters in The Production of Ceramic Pot Filters for Household Water Treatment in Developing Countries. Journal of Water and Health, 13, 587-599. https://doi.org/10.2166/wh.2014.090

[19] Smolina, I., Szymczyk, P. and Chlebus, E. (2016) Influence of Sintering Temperature and Compression Speed on Properties of Hydroxyapatite Disks. Aktualne Problemy Biomechaniki, 11, 121-126.

[20] Eing, K.K., Johar, B., Ho, L. and Zabar, N.Y. (2016) Influence of Sintering Temperature on Crystallization Behavior of Cordierite Synthesized from No N-Stoichiometric Formulation. Proceedings of 2nd International Conference on Green Design and Manufacture, 78, 728-735. https://doi.org/10.1051/matecconf/20167801099 